\title{
Soluble TNF- $\alpha$ receptor and IL-1 receptor antagonist elevation in BAL in active pulmonary TB
}

\author{
T.C.Y. Tsao*, L. Li*, M. Hsieh*, S. Liao**, K.S.S. Chang**
}

\begin{abstract}
Soluble TNF- $\alpha$ receptor and IL-1 receptor antagonist elevation in BAL in active pulmonary TB. T.C.Y. Tsao, L. Li, M. Hsieh, S. Liao, K.S.S. Chang. (C)ERS Journals Ltd 1999.

ABSTRACT: Accumulating evidence suggests that patients with active pulmonary tuberculosis (TB) have an alveolar inflammation resulting in the release of tumour necrosis factor (TNF)- $\alpha$ and interleukin (IL)-1 $\beta$ in bronchoalveolar epithelial fluid. It was proposed that the levels of these cytokines would correlate with clinical status parameters (extent of pulmonary involvement, fever, and body weight loss) and that their naturally occurring inhibitors would be concomitantly released in the local inflammatory sites.

To test this hypothesis lung epithelial lining fluid (ELF) obtained by bronchoalveolar lavage and serum were collected from 29 patients with active pulmonary TB and 15 healthy subjects to determine the levels of these variables using a sandwich enzyme-linked immunosorbent assay (ELISA).

ELF levels of TNF- $\alpha$, soluble (s)TNF receptor I (RI), sTNF-receptor II (RII) and interleukin-1 receptor antagonist (IL-1RA) but not IL-1 $\beta$, and their serum levels except for sTNF-RII and IL-1 $\beta$ were significantly higher in TB patients. Nevertheless, only ELF levels of TNF- $\alpha$ and IL-1 $\beta$ were significantly correlated with disease status. No correlation was found between TNF- $\alpha$ levels and those of sTNF-RI and sTNF-RII, nor between IL-1 $\beta$ and IL-1RA in ELF and serum of TB patients, although there was a significant correlation between sTNF-RI and STNF-RII levels both in ELF and serum.

These findings suggest local release of tumour necrosis factor- $\alpha$ and interleukin- $1 \beta$ and a correlation with disease status. Soluble tumour necrosis factor- $\alpha$ receptors and interleukin-1 $\beta$ receptor antagonist, although increased in lung epithelial lining fluid and serum in tuberculosis patients, were not correlated with tumour necrosis factor-a and interleukin-1 $\beta$ or with disease status.

Eur Respir J 1999; 14: 490-495.
\end{abstract}

Studies in patients with active pulmonary tuberculosis (TB), have shown an increased amount of tumour necrosis factor (TNF)- $\alpha$ in the serum [1,2], and the pleural fluid [3, 4]. Recently, Condos et al. [5] demonstrated elevated levels of TNF- $\alpha$ and interleukin (IL)- $1 \beta$ in bronchoalveolar lavage fluid (BALF) from patients with active pulmonary TB compared with that from healthy subjects. They also found that IL- $1 \beta$ levels were increased in radiographically involved lobes compared with radiographically uninvolved lobes. Levels of TNF- $\alpha$ were equally elevated in both involved and uninvolved lobes. On the contrary, bronchoalveolar cells released increased amounts of both TNF- $\alpha$ and IL-1 $\beta$ from the radiographically involved lobe compared with the radiographically uninvolved lobe in 24-hcell culture supernatants $[5,6]$.

Two types of soluble(s) TNF- $\alpha$ receptor forms (sTNFRs) with molecular masses of $55 \mathrm{kD}$ (sTNF-RI) and $75 \mathrm{kD}$ (sTNF-RII) have been found in human biological fluid [79], and tissue [10, 11]. The function of these TNF-binding proteins is thought to be to regulate the bioavailability of TNF- $\alpha$ in the body. Moreover the soluble form of these proteins may be one component of an autocrine and paracrine regulatory system which limits the toxic effects of systemically circulating TNF [12-14]. The elevation of sTNF-Rs in serum/plasma, reflecting a variety of inflam-

For editorial comments see page 485
*Division of Pulmonary and Critical Care Medicine, Chang Gung Memorial Hospital, Taipei, Taiwan. **Graduate Institute of Clinical Medicine, Chang Gung University, Linko, Taiwan.

Correspondence: T.C.Y. Tsao

Division of Pulmonary and Critical Care Medicine

Chang Gung Memorial Hospital

199 Tun-Hwa North Road

Taipei

Taiwan

Fax: 88633287787

Keywords: Bronchoalveolar lavage fluid IL-1 $\beta$

IL-1 receptor antagonist

pulmonary tuberculosis

soluble TNF receptor forms

TNF- $\alpha$

Received: June 171998

Accepted after revision April 221999

Supported by a Chang Gung University Medical Research Grant CMRP521. matory disorders, has been shown in many diseases, such as cancer [15], rheumatoid arthritis [16], sarcoidosis [17], and human immunodeficiency virus (HIV) infection [18]. In patients with active pulmonary $\mathrm{TB}$ and $\mathrm{TB}$ meningitis, the level of sTNF-Rs was elevated in the serum $[19,20]$ and cerebrospinal fluid (CSF) [21, 22], respectively.

IL-1 receptor antagonist (IL-1RA) a naturally occurring anti-inflammatory protein competitively blocks the binding of IL- $1 \alpha$ and IL- $1 \beta$ to type I and type II IL- 1 receptors, but exerts no agonist activity [23, 24]. IL-1RA is elevated in the serum of patients with a variety of conditions including sepsis [25] and autoimmune diseases [26-28]. Recently, JuFFERMANS et al. [29] described elevated levels of sTNF-RI, sTNF-RII, and IL-1RA in patients with active TB compared with control subjects and stated that the levels of sTNF-RI and IL-1RA were higher in patients with fever and anorexia.

In patients with active pulmonary $\mathrm{TB}$, the local inflammation in the lower respiratory tract may cause the release of these cytokines as well as the shedding of their soluble receptors in bronchoalveolar epithelial fluid. The local levels of these inflammatory cytokines and their receptors or antagonists in BALF would be more representative of pulmonary disease, suggesting that the levels of these cytokines could be correlated with clinical course, such as extent of pulmonary involvement, fever, and body weight loss. In order to address these questions, BALF was 
collected from 29 patients with active pulmonary TB and 15 healthy subjects. The levels of the above cytokines, their receptor forms and antagonists were analysed, after normalization with urea levels to obtain lung epithelial lining fluid (ELF) measures.

\section{Materials and methods}

\section{Patient selection}

The study included 29 patients with active pulmonary TB who were referred to Chang Gung Memorial Hospital. Twenty-two patients were male and nine were female; mean age was $50 \pm 3$ (22-77) (mean \pm SEM (range)) yrs. Pulmonary TB was diagnosed by chest radiographs, clinical pictures and at least one positive sputum smear for acid-fast bacilli and a positive sputum culture for Mycobacterium tuberculosis. None of the patients was immunocompromised, such as with human immunodeficiency virus (HIV) infection or immunosupressant therapy. Fifteen healthy volunteers including 10 males and five females were studied as control subjects. All had normal chest radiographs, no symptoms of disease, and were not taking any medications.

\section{Bronchoscopy and bronchoalveolar lavage}

Bronchoscopy with bronchoalveolar lavage (BAL) was performed as described previously [30]. In brief, patients were pretreated with codein phosphate $(5 \mathrm{mg}$, i.m. $) 30$ min prior to the procedures and midazolam $(2-3 \mathrm{mg}$, i.v. slowly) was given to some patients suffering from anxiety. An Olympus $5.0 \mathrm{~mm}$ fibreoptic bronchoscope (Olympus, Tokyo, Japan) was used and wedged into a forth or fifth subsegmental bronchus of patients under a local spray of xylocain. Lavage was performed using $50-\mathrm{mL}$ aliquots of warmed normal saline introduced by syringe through the bronchoscopic aspiration port. In consideration of the dilution effect of the cytokines and their receptors in the BALF, a fixed volume of $300 \mathrm{~mL}$ saline was infused sequentially, and the return fluid was obtained through the same syringe. Any individuals who could not tolerate the whole procedure or whose returned fluid was $<60 \%$ of total infused volume were excluded. In patients with pulmonary TB, BAL was performed in the radiographically involved bronchi within the first 3 days of antituberculous chemotherapy. In healthy subjects, BAL was performed in the right middle lobe bronchus. All returned fluid was filtered through four layers of sterile gauze, and then pooled and chilled immediately before experimental use. The pooled fluid was spun at $4{ }^{\circ} \mathrm{C}$ at $400 \times g$ for $15 \mathrm{~min}$ to pellet the cells and the supernatant was centrifuged at $80,000 \times g$ for $30 \mathrm{~min}$ at $4^{\circ} \mathrm{C}$ to remove the surfactant-rich fraction. The resultant supernatant was concentrated 10-fold on a 10,000 molecular weight cut-off filter (Amicon, Danvers, MA, USA) under nitrogen. The concentrated supernatant was then divided into $200-\mu \mathrm{L}$ aliquots and rapidly frozen at $-70^{\circ} \mathrm{C}$. Serum was obtained by drawing whole blood using standard procedures on the same day as the BAL.

\section{Determination of cytokines and cytokine receptor forms}

A sandwich enzyme-linked immunosorbent assay (ELISA) was used to detect the levels of cytokines and receptors in the BALF and serum. The kits for TNF- $\alpha$ and IL-1 $\beta$ were purchased from Medgenix (Fleurus, Belgium), and those for sTNF-RI, sTNF-RII as well as IL-1RA were from Quantikine ${ }^{\mathrm{TM}}$ (R\&D, Minneapolis, MN, USA). The frozen aliquots from the BALF and serum were thawed at room temperature for each assay, and the samples were diluted 1:10 for sTNF-RI and sTNF-RII. The kits were used according to the manufacturer's instructions. The minimal detectable dose using a standard curve generated with calibrator diluent was $3 \mathrm{pg} \cdot \mathrm{mL}^{-1}$ for TNF- $\alpha, 10$ $\mathrm{pg} \cdot \mathrm{mL}^{-1}$ for TNF-RI, $5 \mathrm{pg} \cdot \mathrm{mL}^{-1}$ for TNF-RII, $0.06 \mathrm{pg} \cdot \mathrm{mL}^{-1}$ for IL-1 $\beta$ and $6.5 \mathrm{pg} \cdot \mathrm{mL}^{-1}$ for IL-1RA.

\section{Standardization of cytokine levels}

The levels of cytokine in the BALF were standardized to the concentration of urea in serum and BALF to give concentrations per millilitre of ELF. Urea concentration was determined using a modified urease Berthelot reaction in microtitre plates [31]. ELF volume was then calculated using the formula: $\{[$ Urea]BALF/[Urea]Serum $\} \times$ Vol$\mathrm{BALF}=$ VolELF. Urea concentrations were measured on unconcentrated BALF.

\section{Classification of patients by clinical course}

To evaluate whether the levels of the cytokines and soluble receptor forms would be correlated with the clinical course, TB patients were classified by the extent of pulmonary involvement, fever, or body weight loss. A grading of the extent of pulmonary involvement proposed by CROfton and Douglas [32] was adopted to assess the extent of disease: (1) Minimal. Minimal lesions include those which are of slight to moderate density but which do not contain demonstrable cavitation. They may involve a small part of one or both lungs, but the total extent, regardless of distribution, should not exceed the volume of lung on one side which is present above the second chondrosternal junction and the spine of the fourth or the body of the fifth thoracic body; (2) Moderately advanced. Moderately advanced lesions may be present in one or both lungs, but the total extent should not exceed the following limits: disseminated lesions or slight to moderate density which may extend throughout the total volume of one lung, or equivalent in both lungs, dense and confluent lesions which are limited in extent to one third the volume of one lung; total diameter of cavitation, if present must be $<4 \mathrm{~cm}$; and (3) Far advanced. Lesions more extensive than moderately advanced.

All patients received plain posterior, anterior, and lateral chest radiographs and 13 had chest computed tomographic (CT) scans in order to obtain a clearer image for patient classification. The presence of fever was defined when a patient had a core body temperature $>37.5^{\circ} \mathrm{C}$ and body weight loss was confirmed by the patient. To avoid observer bias the radiographs and clinical courses were initially assessed independently by two pulmonary physicians prior to the laboratory studies to give an objective and consistent evaluation.

\section{Statistics}

Values are presented as medians (range). Comparisons between groups were made using the Wilcoxon rank-sum test for unmatched samples, [33] and the correlation 
analysis, using the nonparametric Spearman test. Multivariate analysis of the correlation between cytokines and the clinical course (logistic regression) were performed. The null hypothesis was rejected at $\mathrm{p}<0.05$.

\section{Results}

Levels of tumour necrosis factor- $\alpha$, soluble tumour necrosis factor receptors, interleukin-1 $\beta$ and interleukin-1 receptor antagonist

Figures 1 and 2 show the levels of TNF- $\alpha$, sTNF-Rs, IL-1 $\beta$ and IL-1RA in ELF and serum from patients with pulmonary TB and healthy subjects. The levels of TNF- $\alpha$ and sTNF-RI were significantly increased in ELF and serum from TB patients. Median ELF and serum TNF- $\alpha$ levels in patients with pulmonary TB were $6081.1 \mathrm{pg} \cdot \mathrm{mL}^{-1}$ (2033.1-97689.6) and $23 \mathrm{pg} \cdot \mathrm{mL}^{-1}(9.1-378.4)$, respectively, which was significantly higher than in healthy subjects $\left(133.0 \mathrm{pg} \cdot \mathrm{mL}^{-1}(0-3548.9), \mathrm{p}=0.0001\right.$, and 5.1 $\mathrm{pg} \cdot \mathrm{mL}^{-1}(0-67.2), \mathrm{p}<0.0005$, respectively). Median ELF and serum levels of sTNF-RI in patients with pulmonary TB were 141327.2 (20156.4-2058682.5) and 1361.2 (436-19797.5) pg. $\mathrm{mL}^{-1}$, respectively, which were significantly higher than in the healthy subjects, $\left(3460.4 \mathrm{pg} \cdot \mathrm{mL}^{-1}\right.$ (218.2-11130), $\mathrm{p}=0.0001$ and $699.7 \mathrm{pg} \cdot \mathrm{mL}^{-1}$ (594.7$2184.4), p<0.005$, respectively). Nevertheless, the sTNFRII level significantly increased only in the ELF, (162701.1 $\mathrm{pg} \cdot \mathrm{mL}^{-1}(38529.1-1061712.6)$ versus $3592.5 \mathrm{pg} \cdot \mathrm{mL}^{-1}$ $(681.2-10135.7), \mathrm{p}=0.0001)$, but not in serum (3107.4 $\mathrm{pg} \cdot \mathrm{mL}^{-1}(949.8-14990.1)$ versus $1787 \mathrm{pg} \cdot \mathrm{mL}^{-1}(969.6-$ 6118.1) (median levels of TB patients versus healthy subjects). Median ELF and serum levels of IL- $1 \beta$ were higher in TB patients but the difference was not statistically significant. The median IL-1RA level in patients with pulmonary TB was significantly higher both in ELF (328914.4 pg. $\mathrm{mL}^{-1}(32461.1-473113.9)$ versus 86020 $\left.\mathrm{pg} \cdot \mathrm{mL}^{-1}(33007-560751), \mathrm{p}=0.001\right)$, and serum, $(175.3$ $\mathrm{pg} \cdot \mathrm{mL}^{-1}(40.6-3486.6)$ versus $88.6 \mathrm{pg} \cdot \mathrm{mL}^{-1}(7.13-853)$, $\mathrm{p}<0.005)$.

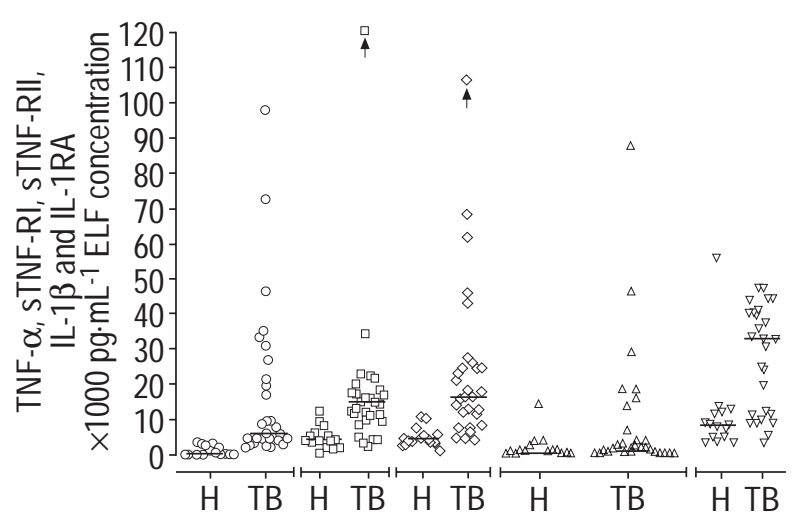

Fig. 1. - Levels of tumour necrosis factor (TNF)- $\alpha(O)$, soluble (s)TNF-receptor I (RI) ( $\square$ ), sTNF-receptor II (RII) ( $\diamond)$, interleukin (IL)$1 \beta(\triangle)$ and IL-1 receptor antagonist (RA) $(\nabla)$ in the lung epithelial lining fluid (ELF) after standardization with urea from patients with active pulmonary tuberculosis (TB) and healthy control subjects $(\mathrm{H})$. The concentrations of sTNF-RI, sTNF-RII, and IL-1RA are expressed in $1 / 10$ of values. Arrows indicate a patient with very high levels of sTNFRI and sTNF-RII respectively $\left(205868.3,106171.3 \mathrm{pg} \cdot \mathrm{mL}^{-1}\right.$, respectively. Horizontal bars indicate median values. The p-values for TB patients versus control subjects were; >0.05 IL-1 $\beta$; 0.001 IL-1RA; and 0.0001 TNF- $\alpha$, sTNF-RI and sTNF-RII.

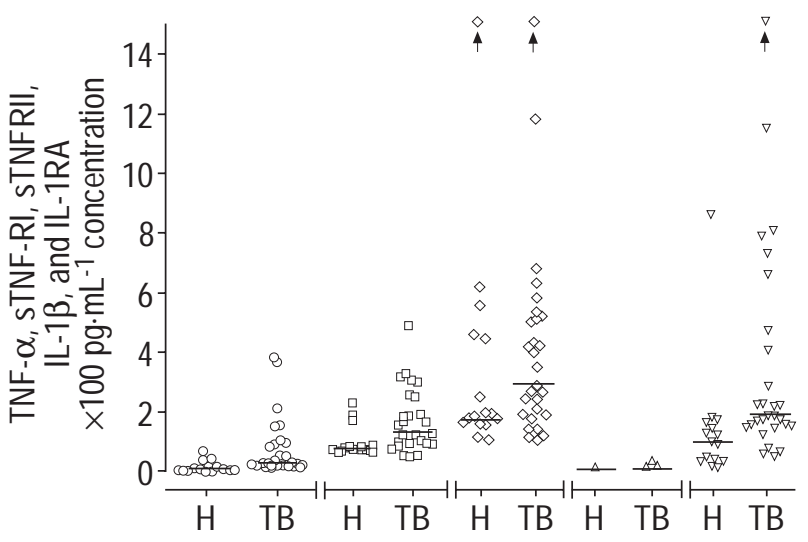

Fig. 2. - Levels of tumour necrosis factor (TNF)- $\alpha(\bigcirc)$, soluble (s)TNF-receptor I (RI) ( $\square$ ), sTNF-receptor II (RII) $(\diamond)$, interleukin (IL)-1 $\beta(\triangle)$ and IL-1 receptor antagonist (RA) $(\nabla)$ in serum from patients with active pulmonary tuberculosis (TB) and healthy control subjects $(\mathrm{H})$. The concentrations of sTNF-RI, sTNF-RII, and IL-1RA are expressed in $1 / 10$ of values. Arrows indicate a patient with very high levels of sTNF-RI and sTNF-RII $\left(1979.8,1466.0 \mathrm{pg} \cdot \mathrm{mL}^{-1}\right.$, respectively) and IL-1RA (3846.6 $\left.\mathrm{pg} \cdot \mathrm{mL}^{-1}\right)$. Horizontal bars indicate median values. ELF: lung epithelial lining fluid. The p-values for TB patients versus control subjects were; $>0.05$ IL-1 $\beta$; and sTNF-RII; 0.002 IL-1RA; 0.0002 TNF- $\alpha$; and 0.004 sTNF-RI. IL- $1 \beta$ was undetectable in all but one control subject and in all but three TB patients.

\section{Correlation of clinical status and cytokine levels}

Figures 3, 4 and 5 show the correlation between clinical status and levels of TNF- $\alpha$, sTNF-Rs, IL- $1 \beta$ and IL-1RA in ELF from patients with pulmonary TB. Patients with far advanced pulmonary involvement had significantly higher ELF levels of TNF- $\alpha$ and IL-1 $\beta$ than patients with moderately advanced and minimal involvement, 24242.1 (2191.7-97689.6) versus 4566.3 (2066.6-30111.9) versus $3891.1(2033.5-5816.8) \mathrm{pg} \cdot \mathrm{mL}^{-1}$, respectively, for TNF$\alpha$ and $9916.3(0-87305.4)$ versus $733.4(0-3526)$ versus

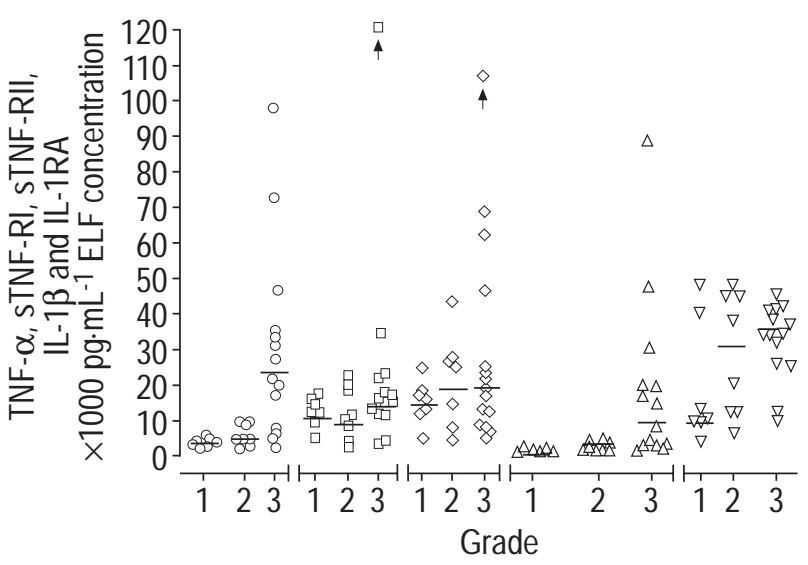

Fig. 3. - Correlation of the extent of pulmonary involvement and levels of tumour necrosis factor (TNF)- $\alpha(O)$, soluble (s)TNF-receptor I (RI) $(\square)$, sTNF-receptor II (RII) $(\diamond)$, interleukin (IL)-1 $\beta(\triangle)$ and IL-1 receptor antagonist (RA) $(\nabla)$ in the lung epithelial lining fluid (ELF) after standardization with urea from patients with active pulmonary tuberculosis. The concentrations of sTNF-RI, sTNF-RII, and IL-1RA are expressed in $1 / 10$ of values. Arrows indicate a patient with very high levels of sTNF-RI and sTNF-RII $\left(205868.3,106171.3 \mathrm{pg} \cdot \mathrm{mL}^{-1}\right.$, respectively). Horizontal bars incidate median values. The p-values for the difference between grade 3 and grades 1 and 2 were; $p=0.001$ TNF- $\alpha$; $>0.05$ sTNF-RI, sTNF-RII, IL-1RA; <0.005 IL-1 $\beta$. Grade 1: minimal, Grade 2: moderately advanced, Grade 3: far advanced pulmonary involvement. 


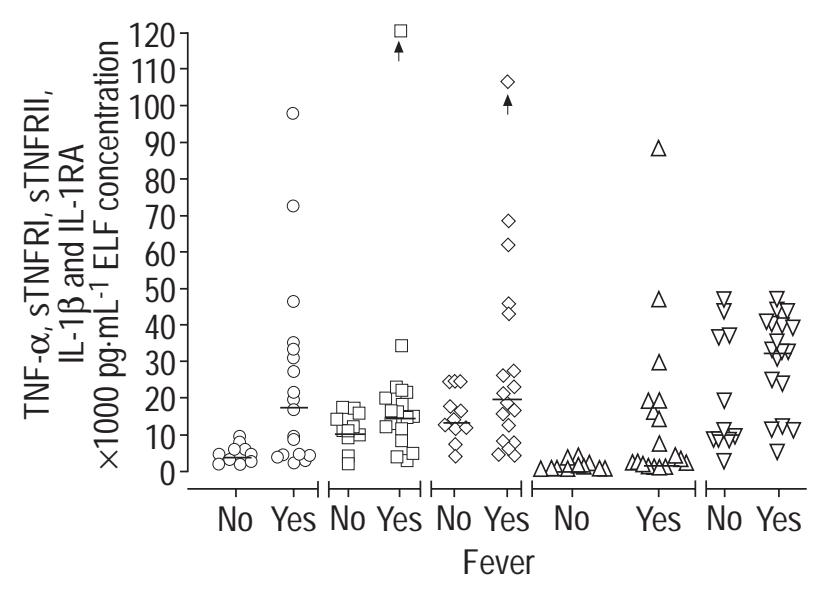

Fig. 4. - Correlation between fever and levels of tumour necrosis factor (TNF)- $\alpha(O)$, soluble (s)TNF-receptor I (RI) ( $\square$ ), sTNF-receptor II (RII) $(\diamond)$, interleukin (IL)-1 $(\triangle)$ and IL-1 receptor antagonist (RA) $(\nabla)$ in the lung epithelial lining fluid (ELF) after standardization with urea from patients with active pulmonary tuberculosis. The concentrations of STNF-RI, sTNF-RII, and IL-1RA are expressed in 1/10 of values. Arrows indicate a patient with very high levels of STNF-RI and STNFRII $\left(205868.3,106171.3 \mathrm{pg} \cdot \mathrm{mL}^{-1}\right.$, respectively). Horizontal bars incidate median values. The $\mathrm{p}$-values for patients with (Yes) versus without (No) fever were; $>0.05$ IL-1RA, sTNF-RI, sTNF-RII; 0.02 TNF- $\alpha$; $<0.005$ IL-1 $\beta$.

$284.5(0-1424.3) \mathrm{pg} \cdot \mathrm{mL}^{-1}$, respectively, for IL-1 $\beta$. Similarly, patients with fever or body weight loss had significantly higher ELF levels of TNF- $\alpha$ and IL- $1 \beta$ than patients without it did, for patients with fever, TNF$\alpha$ : 18260.4 (2191.7-97689.6) versus 4624.6 (2033.19425.7) $\mathrm{pg} \cdot \mathrm{mL}^{-1}$ and IL-1 $\beta$ : 2834 (0-87305.4) versus $284.5(0-3526) \mathrm{pg} \cdot \mathrm{mL}^{-1}$; for patients with body weight loss, TNF- $\alpha$ : 12745.8 (2762.1-97689.6) versus 4624.6 (2033.1-35144.9) pg.mL $\mathrm{mL}^{-1}$ and IL-1 $\beta: 3150.5(0-87305.4)$ versus $902.4(0-46013.2) \mathrm{pg} \cdot \mathrm{mL}^{-1}$. After adjustment of the cytokine variable levels for the clinical status by logistic regression, the ELF TNF- $\alpha$ level was the significant

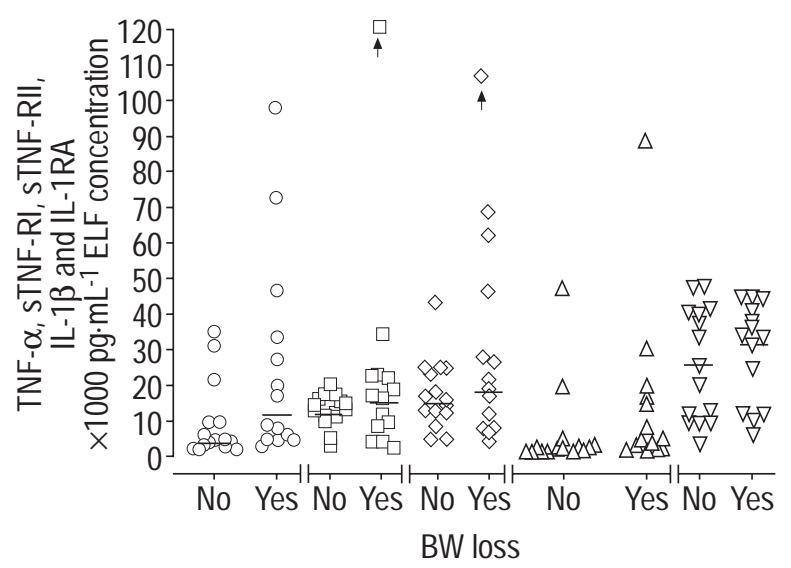

Fig. 5. - Correlation of body weight (BW) loss and levels of tumour necrosis factor (TNF)- $\alpha(O)$, soluble (s)TNF-receptor I (RI) ( $\square$ ), sTNFreceptor II $(\mathrm{RII})(\diamond)$, interleukin (IL)-1 $\beta(\triangle)$ and IL-1 receptor antagonist (RA) $(\nabla)$ in the lung epithelial lining fluid (ELF) after standardization with urea from patients with active pulmonary tuberculosis. The concentrations of STNF-RI, sTNF-RII, and IL-1RA are expressed in 1/10 of values. Arrows indicate a patient with very high levels of sTNF-RI and sTNF-RII $\left(205868.3,106171.3 \mathrm{pg} \cdot \mathrm{mL}^{-1}\right.$, respectively). Horizontal bars incidate median values. The $\mathrm{p}$-values for patients with (Yes) versus without (No) BW loss were; >0.05 sTNF-RI, sTNF-RII, IL-1RA; 0.05 TNF- $\alpha$, IL- $1 \beta$. predictor for the clinical course including far advanced pulmonary involvement and fever. The BALF levels of STNF-RI, sTNF-RII and IL-1RA in TB patients did not correlate with the disease status. There was no correlation between the serum levels of TNF- $\alpha$, TNF-Rs, IL-1 $\beta$ and IL-1RA and the clinical status (data not shown).

Correlation between tumour necrosis factor- $\alpha$ and soluble tumour necrosis factor receptors

Since it is possible that increased TNF- $\alpha$ itself is a stimulating factor for production of soluble TNF receptors, the relationship between TNF- $\alpha$ and its two receptor forms was investigated. A very poor correlation was found between the levels of TNF- $\alpha$ and sTNF-RI $(r=0.42)$ and sTNF-RII $(r=0.36)$ in the ELF of TB patients. The serum level of TNF- $\alpha$ also failed to show a good correlation with the level of sTNF-RI $(r=0.45)$ and sTNF-RII $(r=0.34)$ in TB patients. There was no significant correlation between the levels of TNF- $\alpha$ and sTNF-RI as well as sTNF-RII in the healthy subjects. The level of sTNF-RI showed a significant correlation with sTNF-RII in the ELF ( $r=0.85$, $\mathrm{p}=0.0001)$ and serum $(\mathrm{r}=0.68, \mathrm{p}=0.001)$ from TB patients. A significant correlation between sTNF-RI and sTNF-RII was also found in ELF but not in the serum from healthy subjects. No correlation was found between IL-1 $\beta$ and IL$1 R A$ in ELF and serum from either TB patients or healthy subjects. There was no correlation between ELF levels and serum levels of TNF- $\alpha$, sTNF-RI, sTNF-RII, IL- $1 \beta$ and IL-1RA.

\section{Discussion}

A set of observations are described here, which show that the ELF from TB patients presented significantly higher levels of TNF- $\alpha$ and its soluble receptor forms (sTNF-RI, sTNF-RII) than that of healthy control subjects. Moreover, the ELF levels of TNF- $\alpha$ and IL- $1 \beta$ were significantly correlated with the clinical status, i.e. the patient with more advanced disease, with fever or with body weight loss had significantly higher levels of TNF- $\alpha$ and IL-1 $\beta$. Nevertheless, a correlation between the ELF levels of sTNF-RI, sTNF-II and IL-1RA and the clinical status was not found. Also, there was no correlation between the serum levels of TNF- $\alpha$, sTNF-RI, sTNF-RII, IL-1 $\beta$, and IL-1RA and the clinical course. A good correlation, was not found between the levels of TNF- $\alpha$ and those of both sTNF-RI and sTNF-RII in the ELF and serum of TB patients, although, there was a significant correlation between sTNF-RI and sTNF-RII levels both in the ELF and the serum from TB patients.

Recently, two studies have described bronchoalveolar cells from the site of active pulmonary TB spontaneously releasing more TNF- $\alpha$ and IL- $1 \beta$ than cells from healthy subjects $[5,6]$. One of these studies also showed increased levels of TNF- $\alpha$ and IL-1 $\beta$ in the BALF compared with those from healthy subjects $[5,6]$. In the current study, the levels of TNF- $\alpha$, sTNF-RI, sTNF-RII, IL- $1 \beta$ and IL-1RA were measured in the ELF. It was found that ELF levels of these proteins, except for IL-1 $\beta$, were significantly higher in TB patients than in healthy subjects. Indeed higher levels of IL-1 $\beta$ were found compared to healthy subjects, $1441.5(0-87305.4)$ versus $815(0-14039) \mathrm{pg} \cdot \mathrm{mL}^{-1} \mathrm{ELF}$, but the $p$-value was not significant because of the large 
data variation. The positive correlation between the disease status and levels of TNF- $\alpha$ and IL- $1 \beta$ may suggest that bronchoalveolar cells are activated and release proinflammatory cytokines in the local epithelial fluid after exposure to $M$. tuberculosis. The release of cytokines tends to be local in nature and corresponds to the load of TB bacilli and these cytokines may reach the circulation later. Nevertheless, a significant correlation between the ELF and serum levels for each variable of TNF- $\alpha$, sTNFRI, sTNF-RII, IL-1 $\beta$ and IL-1RA was not found. Therefore, the reasons for the significantly increased serum levels of TNF- $\alpha$, sTNF-RI and IL-1RA in this study might be complex.

It is not yet clear whether the soluble TNF- $\alpha$ receptor forms are TNF- $\alpha$ inhibitors, or whether they prolong TNF- $\alpha$ effects by stabilizing TNF- $\alpha$. In 1990, FOLEY et al. [34] first described the inhibition of TNF- $\alpha$ toxicity caused by sera from most TB patients. The soluble forms of TNF- $\alpha$ receptors had inhibitory properties against TNF- $\alpha[12,14]$, and were elevated in serum/plasma from patients with a variety of disorders $[15,18]$. Recently, a few studies have demonstrated significantly increased levels of sTNF-RI and sTNF-RII in serum from patients with active pulmonary TB $[19,20,29]$. In the current study, significantly higher levels of sTNF-RI were found, but not sTNF-RII, in serum from TB patients. This was caused by a higher baseline of sTNF-RII in healthy subjects associated with a milder increase of this receptor in TB patients. Nevertheless, significantly higher levels of both sTNF-RI and sTNF-RII were found in the ELF. JUFFERMANS et al. [29] also demonstrated higher serum levels of sTNF-RI and IL-1RA in TB patients with fever and anorexia. In the current study, ELF levels of TNF- $\alpha$ and IL- $1 \beta$ but not serum levels of TNF- $\alpha$, sTNF-Rs, IL$1 \beta$ or IL-1RA were found to be correlated with the disease status, including extent of pulmonary involvement, fever and body weight loss. One study described a significant positive correlation between serum levels of TNF- $\alpha$ and both sTNF-RI and sTNF-RII [20]. In this study no strong correlations were found between TNF- $\alpha$ and sTNF-RI and sTNF-RII in the ELF or in the serum from TB patients, although, there was a significant correlation between sTNF-RI and sTNF-RII levels both in the ELF and serum from TB patients. These negative findings may indicate that the regulation of the release of soluble TNF$\alpha$ receptors in response to $\mathrm{TB}$ infection is complex. BARGETZI et al. [35] stated that in patients given an intravenous infusion of recombinant human (rh)IL-1 $\beta$, a maximum 7-8-fold increase of sTNF-RI, and a 2-3-fold increase of TNF-RII were seen. These results support diversity of the increase of soluble TNF- $\alpha$ receptors. In this study the significant increases of sTNF-RII in the ELF but not the serum may only hint at the difference between the local (bronchoalveolar) and the systemic response of this receptor to $M$. tuberculosis infection. From these data it is not possible to deduce whether TNF$\alpha$ induces its soluble receptors or whether these molecules are instead co-regulated.

IL-1 $\beta$ has been demonstrated to be an important cytokine in granulomatous alveolitis in a bacille CalmetteGuérin (BCG)-infected mouse [36]. Bronchoalveolar cells $[5,6]$ or peripheral monocytes [37-39] from patients with active pulmonary TB have been shown to release significantly greater amounts of this cytokine than did healthy subjects. In this study, although the median ELF level of IL- $1 \beta$ in TB patients was higher than in healthy subjects, there was a borderline $p$-value. However, it was found that both the ELF and serum levels of IL-1 $\beta$ were significantly higher in patients with more advanced disease, with fever or with body weight loss. These findings suggest that the expression and release of IL-1 $\beta$ may need exposure to larger amount of $M$. tuberculosis and with more severe infection. The IL-1RA level is elevated in the serum of patients with many conditions such as sepsis and autoimmune diseases [25-27]. The effects of IL-1RA on blocking receptor binding of IL-1 during the acute-phase response may serve to suppress the inflammatory consequences of early IL-1 release [28]. In this study it was found that the level of IL-1RA was high in both the ELF and serum from TB patients. Because the level of IL-1 $\beta$ in the serum was mostly undetectable in both healthy subjects and TB patients, no correlation was found between IL-1 $\beta$ and IL-1RA. However, no correlation was found in the ELF of healthy subjects or TB patients either. AREND et al. [40] stated that the production of these two proteins in human is regulated differently. The expression of IL$1 \mathrm{RA}$ in response to mycobacterial infection may be not related, or only partially related, to the presence of IL-1 $\beta$.

In conclusion, a significantly higher level of tumour necrosis factor- $\alpha$ was found both in the lung epithelial lining fluid and in the serum of patients with active pulmonary tuberculosis. Significant elevations of soluble tumour necrosis factor receptor I and soluble tumour necrosis factor receptor II were also found in the lung epithelial lining fluid of these patients. Higher lung epithelial lining fluid levels of interleukin-1 $\beta$ in tuberculosis patients were also found but the p-value was not significant because of the large data variation. Increased levels of interleukin-1 receptor antagonist were found both in the lung epithelial lining fluid and in the serum from tuberculosis patients. The lung epithelial lining fluid levels of tumour necrosis factor- $\alpha$ and interleukin- $1 \beta$ were significantly higher in patients with more advanced disease, with fever or with body weight loss. These findings suggest that tumour necrosis factor- $\alpha$, soluble tumour necrosis factor receptor I, soluble tumour necrosis factor II, interleukin- $1 \beta$ and interleukin-1 receptor antagonist are released in local inflammatory sites and play an important role in tuberculosis infection. A further study focusing on regulation of tumour necrosis factor- $\alpha$ and its soluble receptor forms, interleukin-1 $\beta$ and interleukin- 1 receptor antagonist in response to Mycobacterium tuberculosis infection may be important in investigating the pathogenesis and treatment of tuberculosis.

Acknowledgements. The authors would like to thank the physicians and patients at Chang Gung Memorial Hospital for their collaboration and cooperation. They would also like to thank $\mathrm{C}-\mathrm{H}$. Chang (President, Chang Gung University) for encouraging research into tuberculosis.

\section{References}

1. Theilmann L, Meyer U, Kommerell B, Dierkesmann R, Moiler A. Tumor necrosis factor- $\alpha$ in the serum of patient with sarcoidosis, tuberculosis or lung cancer. Pneumologie 1990; 44: 735-738.

2. Vanham G, Edmonds K, Qing L, et al. Generalized immune activation in pulmonary tuberculosis: co-activation with HIV infection. Clin Exp Immunol 1996; 103: 30-34. 
3. Barnes PF, Fong SJ, Brennan PJ, Towmey PE, Mazumder A, Modlin RL. Local production of tumor necrosis factor and IFN- $\gamma$ in tuberculous pleuritis. J Immunol 1990; 145: 149-154.

4. Barnes PF, Lu S, Abrams JS, Wang E, Yamamura M, Modlin RL. Cytokine production at disease in human tuberculosis. Infect Immun 1993; 61: 3428-3489.

5. Condos R, Rom WN, Liu YM, Schluger NW. Local immune responses correlated with presentation and outcome in tuberculosis. Am J Respir Crit Care Med 1998; 157: 729-735.

6. Law K, Weiden M, Harkin T, Tchou-Wong K, Chi C, Rom $\mathrm{WN}$. Increased released of interleukin-1 $\beta$, interleukin-6 and tumor necrosis factor- $\alpha$ by bronchoalveolar cells lavaged from involved sites in pulmonary tuberculosis. $\mathrm{Am}$ J Respir Crit Care Med 1996; 153: 799-804.

7. Peetre C, Thysell N, Grubb A, Olsson I. A tumor necrosis factor binding protein is present in human biological fluids. Eur J Haematol 1988; 41: 414-419.

8. Seckinger P, Issaz S, Dayer J. Purification and biologic characterization of a specific tumor necrosis factor a inhibitor. J Biol Chem 1989; 264: 11966-11973.

9. Engelmann H, Novick D, Wallach D. Two tumor necrosis factor-binding proteins purified from human urine. J Biol Chem 1990; 265: 1531-1536.

10. Abdolrasulnia R, Shepherd VL. Purification of type I and type II tumor necrosis factor receptors from human lung tissue. Am J Respir Cell Mol Biol 1992; 7: 42-48.

11. Ryfell B, Brockhaus M, Durmuller U, Gudat F. TNF receptors in lymphoid tissues and lymphomas: source and site of action of tumor necrosis factor $\alpha$ (TNF $\alpha$ ). Am J Pathol 1991; 139: 7-15.

12. Vilcek J, Lee TH. Tumor necrosis factor. $J$ Biol Chem 1991; 266: 7313-7316.

13. Tartaglia LA, Goeddel DV. Two TNF receptors. Immunol Today 1992; 13: 151-153.

14. Aderka D, Engelmann H, Maor Y, Brakebusch C, Wallach D. Stabilization of the bioactivity of tumor necrosis factor by its soluble receptors. J Exp Med 1992; 175: 323-339.

15. Aderka D, Engelmann H, Hornik V, et al. Increased serum levels of soluble receptors from tumor necrosis factor in cancer patients. Cancer Res 1991; 151: 5602-5607.

16. Cope AP, Aderka D, Doherty M, et al. Increased levels of soluble tumor necrosis factor receptors in the sera and synovial fluid of patients with rheumatic diseases. Arthritis Rheum 1992; 35: 1160-1169.

17. Nakayama T, Hashimoto S, Amemiya E, Horie T. Elevation of plasma-soluble tumor necrosis factor receptors (TNF-R) in sarcoidosis. Clin Exp Immunol 1996; 104: 318-324.

18. Kalinkovich A, Engelmann H, Harpaz N, et al. Elevated serum levels of soluble tumor necrosis factor receptors (sTNF-R) in patients with HIV infection. Clin Exp Immunol 1992; 189: 351-355.

19. Kawaguchi H, Ina Y, Ito S, et al. Serum levels of soluble tumor necrosis factor (TNF) receptors in patients with pulmonary tuberculosis. Kekkaku 1996; 71: 259-265.

20. Onohara Y, Tomada K, Nakaya M, et al. Investigation of soluble tumor necrosis factor receptors in patients with active tuberculosis. Kekkaku 1996; 171: 435-438.

21. Rydberg J, Miorner H, Chandramuki A, Lantz M. Assessment of a possible imbalance between tumor necrosis factor (TNF) and soluble TNF receptor forms in tuberculous infection of the central nervous system. $J$ Inf Dis 1995; 172: 301-304.

22. Mastroianni CM, Paoletti F, Lichtner M, D'Agostino C, Vullo V, Delia S. Cerebrospinal fluid cytokines in patients with tuberculous meningitis. Clinc Immunol Immunopathol 1997; 84: 171-176.
23. Dripps DJ, Brandhuber BJ, Thompson RC, Eisenberg SP. Interleukin-1 (IL-1) receptor antagonist binds to the 80$\mathrm{kDa}$ IL-1 receptor but does not initiate, IL-1 signal transduction. J Biol Chem 1991; 266: 10331-10336.

24. Granowitz EV, Clarck BD, Mancilla C, Dinarello CA. Interleukin-1 receptor antagonist competitively inhibits the binding of interleukin-1 to the type II interleukin receptor. J Biol Chem 1991; 266: 14147-14150.

25. Granowitz EV, Santos AA, Poutsiaka DD, Cannon DW. Production of interleukin-1-receptor antagonist during experimental endotoxemia. Lancet 1991; 338: 14231424.

26. Gabay C, Gay-Croisier F, Roux-Lombard P, et al. Elevated serum levels of interleukin 1 receptor antagonist in polymyositis/dermatomyositis. A biologic marker of disease activity with a possible role in the lack of acute-phase protein response. Arthritis Rheum 1994; 37: 1744-1751.

27. Gabay C, Cakir N, Roux-Lombard P, et al. Circulating levels of tumor necrosis factor soluble receptors in systemic lupus erythematosus are significantly higher than in other rheumatic diseases and correlated with disease activity. J Rheumoatol 1997; 24: 303-308.

28. Gabay C, Smith MF, Eldlen D, Arend WP. Interleukin 1 receptor antagonist (IL-1RA) is an acute phase protein. $J$ Clin Invest 1997; 99: 2930-2940.

29. Juffermans NP, Verbon A, van Deventer SJH, van Deutekom H, Speelman P, van der Poll T. Tumor necrosis factor and interleukin-1 inhibitors as markers of disease activity of tuberculosis. Am J Respir Crit Care Med 1998; 157: 1328-1331.

30. Hyers TM, Tricomi SM, Dettenmeier PA, Fowler AA. Tumor necrosis factor levels in serum and bronchoalveolar lavage fluid of patients with the adult respiratory distress syndrome. Am Rev Respir Dis 1991; 144: 268-271.

31. Jones KP, Edwards JH, Reynolds SP, Peters TJ, Davies $\mathrm{BH}$. A comparison of albumin and urea as reference markers in bronchoalveolar lavage fluid from patients with interstitial lung disease. Eur Respir J 1990; 3: 152-156.

32. Crofton SJ, Douglas A. Respiratory Disease. 3rd ed. London, Blackwell, 1981; 265-271.

33. Altman DG. Practical Statistics for Medical Research. Fourth edition, London, Chapman \& Hall, 1991; 194-197.

34. Foley N, Lambert C, McNicol M, Johnson N, Rook GAW. An inhibitor of the toxicity of tumor necrosis factor in the serum of patients with sarcoidosis, tuberculosis and Crohn's disease. Clin Exp Immunol 1990; 80: 395-399.

35. Bargetzi MJ, Lantz M, Smith CG, et al. Interleukin-1 $\beta$ induces interleukin-1 receptor antagonist and tumor necrosis factor binding protein in hurnans. Cancer Res 1993; 53: 4010-4013.

36. Denis M. Interleukin-1 (IL-1) is an important cytokine in granulomatous alveolitis. Cell Immun 1994; 157: 70-80.

37. Takashima T, Ueta C, Tsuyuguchi I, Kishimoto S. Production of tumor necrosis factor alpha by monocytes from patients with pulmonary tuberculosis. Infect Immun 1990; 58: 3286-3292.

38. Tsukaguchi K, Yoneda T, Yoshikawa M, et al. Case study of interleukin-1 beta, tumor necrosis factor alpha and interleukin-6 production in peripheral blood monocytes in patients with diabetes mellitus complicated by pulmonary tuberculosis. Kekkaku 1992; 67: 755-760.

39. Chensue SW, Davey MP, Remick DG, Kunkel SL. Release of interleukin-1 by peripheral blood mononuclear cell in patients with tuberculosis and active inflammation. Infect Immun 1986; 52: 341-343.

40. Arend WP, Smith NIF NIF, Jason RW, Joslin FG. IL-1 receptor antagonist and IL-1 production in human monocytes are regulated differently. J Immunol 1991; 147: $1530-1536$. 